\title{
Therapeutic Lasers and Skin Welding Applications
}

\author{
Haşim Özgür Tabakoğlu ${ }^{1}$ and Ayşen Gürkan Özer ${ }^{2}$ \\ ${ }^{1}$ Fatih University, Institute of Biomedical Engineering, İstanbul, \\ 2İstanbul Technical University, Faculty of Art and Sciences, İstanbul, \\ Turkey
}

\section{Introduction}

\subsection{Laser physics}

Laser systems used in therapeutic medical field are specialized in terms of energy production and optical delivery mechanisms. It is favorable that medical lasers should have compact design especially important for a surgeon who is working in operation room where bulky medical devices occupy wide spaces. With the developing technology, especially in diode electronics, lasers of dimensions as small as i.e. $20 \times 20 \times 20 \mathrm{~cm}^{3}$ can be produced. Laser physics can be overviewed elsewhere written in any physics or biomedical books. Here we will only mention about important mechanisms and general knowledge.

\subsection{Laser light}

Since the word LASER is an acronym standing for Light Amplification by the Stimulated Emission of Radiation, the term optical amplifier can be considered as a concise laser device. In the atomic structure, electrons being in the quantized energy levels can only move with respect to the Quantum Physics rules. As seen on Figure 1, motions of the electrons, in other words electronic transitions cause the three main phenomena producing laser light. These are spontaneous absorption, spontaneous emission, and stimulated emission that determine the main features of the laser light.
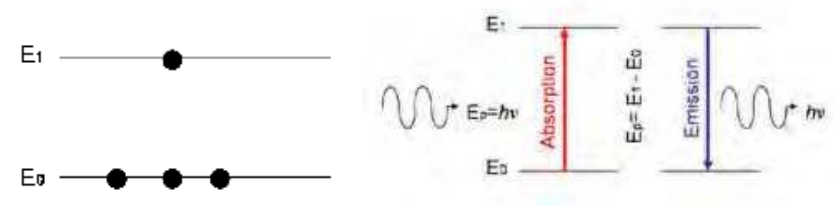

Fig. 1. Quantized energy levels, absorption and emission phenomena.

Spontaneous absorption, or simply absorption is the increase in an electron's energy level by capturing a photon's energy. The captured energy here is the key process meaning the exact 
difference between the energy levels as the word "exact" means quantized here. After the absorption, the atom changes its state from stable ground energy level $\mathrm{E}_{0}$ to unstable excited energy level $\mathrm{E}_{1}$, Figure 2 .

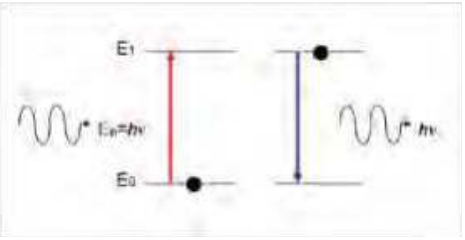

Fig. 2. Schematic drawing of absorption.

Becoming unstable, the atom needs to be stable again so it emits a photon to become stable again. This is called emission. During emission, the captured photon is released and luminescence takes place. If the emission occurs spontaneously, the process is named spontaneous emission, Figure 3; but we are not interested in this kind of emission in this text.

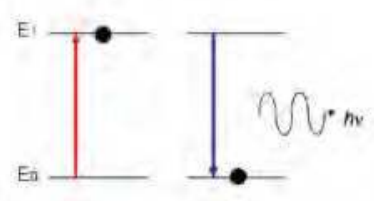

Fig. 3. Schematic drawing of spontaneous emission.

The last key process, stimulated emission occurs when another photon containing exactly the same energy between $\mathrm{E}_{0}$ and $\mathrm{E}_{1}$ hits, or "stimulates" the electron being at the excited energy level $E_{1}$, Figure 4 . After this step, there are two photons identically the same with each other. Their directions, wavelengths, and phases are the same. These two photons which form the unique laser light are called coherent.

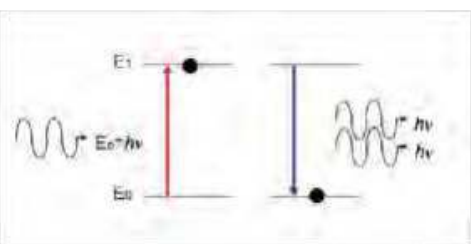

Fig. 4. Schematic drawing of stimulated emission.

In order to keep laser light under control, its production requires some specifications which are main parts of a laser devise: resonator, medium, and pump.

The resonator, or cavity, can be almost considered as a closed box. There are two mirrors generally located face to face. One of them, $\mathrm{M}_{1}$, is $100 \%$ reflective, and the other one, $\mathrm{M}_{2}$, is 98-99\% reflective. $M_{2}$ has a hole to allow the photons reflected from $M_{1}$ to escape and the output is named as laser light. 
The medium is the substance to be used for generating photons from its electrons indeed. It is situated in the resonator and determines the wavelength. Since the laser medium can be solid, liquid, or gas, the wavelength range can be easily selected from UV to IR.

The pump is the energy source which starts the population inversion and it can be in several ways such as electrical, optical, thermal, or chemical. The process population inversion is the most important step of laser light production and can be basically summarized as to make the number of atoms in the excited state more than the number of atoms in the ground state.

In short, when the pump, resonator and medium come together, the pump starts population inversion and photons released by spontaneous emission cause much more photons released by stimulated emission. Thus photons proliferate and start to move back and forth between the mirrors $\mathrm{M}_{1}$ and $\mathrm{M}_{2}$ until reaching certain intensity then pure laser light quits the resonator that becomes the laser device.

\subsection{Interaction mechanisms}

Interaction of radiation with matter is summarized above, but, when the matter is tissue specifically, the interaction mechanisms become important. There are mainly five different laser-tissue interaction mechanisms observed on tissues. These are photochemical, photothermal, photoablation, plasma-induced ablation, and photodisruption, see Figure 5. Main concern of these mechanisms is the deposition of delivered laser energy which is determined by laser parameters such as wavelength, spot size, exposure time, pulse duration, repetition rate, etc.; optical tissue properties such as anisotropy factor, absorption and scattering coefficients; and, thermal tissue properties such as heat capacity, heat conduction, tissue density, etc. As a result of these parameters, there is one more important parameter called thermal relaxation time.

As seen on Figure 5, if the exposure time lasts long, power density decreases; if the power density increases, exposure time decreases, but both are almost always kept in between 1 $\mathrm{J} / \mathrm{cm}^{2}$ and $1000 \mathrm{~J} / \mathrm{cm}^{2}$.

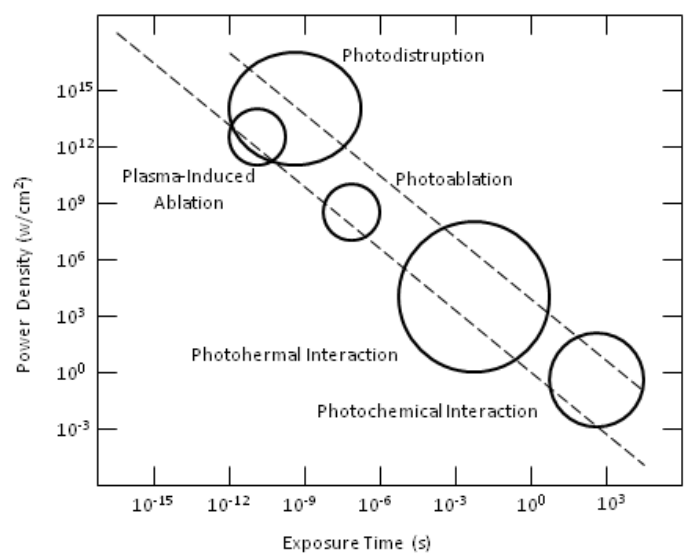

Fig. 5. Laser-tissue interaction types. (Modified from Niemz.) [1] 
Photochemical interactions occur at very low power densities with relatively long exposure time, from seconds to days. One of the best known applications is a kind of tumor treatment, Photo-Dynamic Therapy (PDT), which uses a catalytic photosensitizer to destroy the tumor.

Photothermal interactions are very common medical applications and occur at relatively low power densities. Depending on the exposure time, four major effects are observed on the tissue; hyperthermia, coagulation, carbonization, and vaporization which determine the type of treatment whether it is diagnostic or therapeutic. Energy of the photons is absorbed by the tissue and transformed into heat, and, depending on heat propagation and deposition in tissues, the photothermal effects originate. For example at room temperature $\left(25^{\circ} \mathrm{C}\right)$, a tissue normally can heat up to $37^{\circ} \mathrm{C}$ without any damage and after this point keeps heating with a mild change in color. This change is named as hyperthermia and the tissue can still heal. After $50^{\circ} \mathrm{C}$, enzyme activity decreases, cells cannot move and the irreversible damage coagulation (a kind of sclerosis) occurs at $60^{\circ} \mathrm{C}$. Actually, the temperature window $60-65^{\circ} \mathrm{C}$ are very sensitive for the collagen structures covering tissues, because this is the basic principle of tissue welding. If the coagulated tissue continues to heat, the water molecules being in the tissue constituents start to vaporize (vaporization) and pressure starts to appear at the inner structures at $100^{\circ} \mathrm{C}$. Consequently, tissues start to leave the application area, thus, thermal ablation happens with the thermal-mechanical effects. Since the expansion of the pressure causes tissues to tear and burst, this type of ablation is completely different from the photoablation. As a result of this, damages at the vicinity and the ablation crater on the application surface form. Beyond $200^{\circ} \mathrm{C}$, carbonization starts and is used to burn some kinds of tumors on the surface. When the temperature reaches $300^{\circ} \mathrm{C}$, melting is observed. All these effects can be seen on Figure 6 [2].

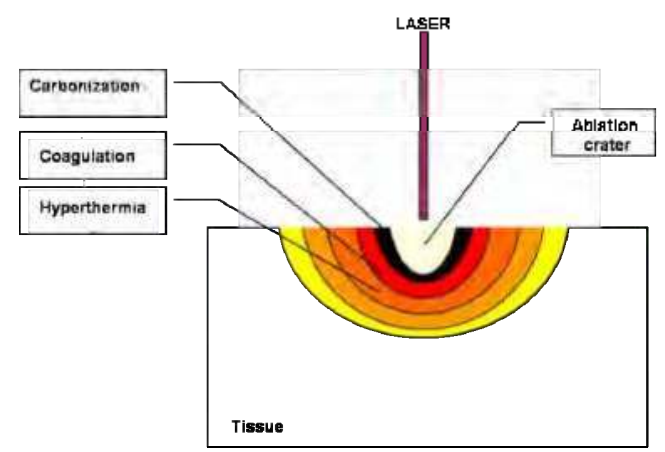

Fig. 6. Photothermal effects observed inside biological tissue (Modified from Niemz) [1].

Photoablation needs high energy photons from UV region of the electromagnetic spectrum, so it occurs at relatively high power densities with short exposure times. Since the main principle here is directly breaking the molecular bonds, edges of the ablation volume are very smooth, clean, and regular. This process is mostly used for corneal shaping to achieve vision correction in Ophthalmology.

Plasma-induced ablation is the ablation by ionizing plasma formation. Seen on the Figure $\mathrm{x}$, when the power density reaches $1012-1016 \mathrm{~W} / \mathrm{cm}^{2}$, an electric field larger than the average Coulombic attraction force between the electrons and the nuclei occurs and creates a very 
large free electron density, the plasma, causing dielectric breakdown of the tissue. This is called optical breakdown and the plasma absorbs very well from the UV to IR and creating very clean ablation allows many treatments especially used in Dentistry.

Photodisruption is achieved by plasma formation again and observed on the soft tissues or fluids. Since the formation of plasma needs higher energies, shock waves appear in the tissue and 'disrupt' the tissue structure with a mechanical effect. Because of both the plasma-induced ablation and photodisruption shares a big common area on the graphic, Figure $x$, it is difficult to distinguish them from each other [1-3].

\section{Skin welding applications}

Improved wound healing strategies tried to be investigated by biomedical research groups. Sealing a cut with beam of light to its immaculate state like in science fiction movies seems far to be accomplished that is like earlier men's desire to fly. Will humanity eventually be able to come closer the supernatural healing? The efficacy of wound closure strategies will need to be tested step by step in scientific manner.

Closure or anastomosis of tissue by laser welding and soldering occur due to two phenomena: First one is physical that is thermal and optical interactions of laser with tissue and the second one is biological that is modifications of connective tissue proteins during heating process and reassembly. Since the first application in 1964 on small blood vessels with Nd:YAG laser by Yahr and Strully [4], different laser systems have been tried at different tissue types, have transferred from laboratory testing to approved clinical practice [5]. The first attempt came from Schober et al [6] about finding molecular level changes of laser irradiated tissue but process that is change in collagen fiber bundles with interdigitation of altered individual tropocollagen units, denaturation and cross-linking of tissue proteins seems to be structural mechanism of the welding effect, could not be understood thoroughly [7-14].

Natural tissue repair is considered as three phases and followed by histological staining techniques: (I) cellular migration and inflammation for the very first days; (II) fibroblasts proliferation for 2 to 4 weeks, with new collagen synthesis; and (III) remodeling from 1 month to 1 year. This process includes collagen cross-linking and active collagen turnover [15], in general. Healing phase further divided into phases of coagulation, inflammation, matrix synthesis and deposition, angiogenesis, fibroplasia, epithelialization, contraction, and remodeling, [16-18] in detail. Fibroblast cells, as being the principal source of collagen and wound connective tissue, begin to synthesize and secrete measurable amounts of extracellular collagen on the second or third day after wounding. Polymerization of collagen fibers occurs in extracellular wound environment where monomers of collagen are secreted. Tensile strength of collagen fibers increases as increase in covalent cross-linking among fibers. At 1 week following wounding, immature collagen fibers become histologically apparent in the wound [16, 19-21].

Requirement of mechanical assembly in any skin cuts or surgical incisions was carried out by using conventional mechanical closure techniques for tissue bonding (sutures, staples, and adhesives) are highly reliable procedures that have proven themselves over the years to be good clinical practice [22-28]. These methods are favored due to reliability, cost- 
effectiveness and suitability of any type of tissue. The primary function of the suture is to maintain tissue approximation during healing. Sutures placed in the dermal layer provide tensile strength, and control tension for the outer layer [22, 29, 30]. In the selection of a suture, a patient health status, age, weight, and the presence or absence of infection are as important as the biomechanical properties of the suture, individual wound characteristics, anatomic location, and a surgeon's personal preference and experience in handling a suture material. Fundamental intention to any surgeon is choosing a method of closure that affords a technically easy and efficient procedure, secure closure, minimal pain and scaring. However, these conventional fasteners cause tissue injury due to their mechanical penetration. Foreign body reaction is given rise because of nature of materials used [31, 32]. Tissue injury and foreign-body reaction can induce inflammation, granuloma formation, scarring, and stenosis [33]. Sutures may not be suitable for microsurgical or minimally invasive endoscopic applications [34]. Precision of alignment is so hard for staples and clips due to relatively large force requirements for positioning. Most importantly, none of these fasteners produces a watertight seal over the repair [35]. Besides the mechanical closure methods, FDA approved biological and non-biological topical skin adhesive chemicals such as fibrin glue and cyanoacrylate based compounds have been used in skin edges of wounds from surgical incisions, and simple, trauma-induced lacerations [27, 36-38]. Adhesives may be used together with dermal stitches although it cannot be used in place of that technique. Chemical bonding of tissue has contraindications over hypersensitive patients to cyanoacrylate or formaldehyde, wound with evidence of infection, mucosal surfaces [39, 40]. They are toxic to the tissues, not absorbed in the normal wound healing process, and cause foreign-body granulomas and allergic reactions.

Increased instant wound strength,fluid-tight closure, low level risk of infection are the advantages of laser tissue closure over conventional methods [35, 41-44]. On the other hand, thermal damage to tissue was the biggest handicap of this technique. This is an unwanted event opposed to the objective of laser tissue repair methods that is to obtain coagulation of a desired volume of tissue with minimal effects in the surrounding tissue. Endpoint decision for the tissue apposition and poor reproducibility are the other negative sides of application [45]. Optimization of laser tissue closure is quite hard due to high number of tissue optical and thermal parameters as well as laser parameters. Tissue optical and thermal parameters cannot be changed but by addition of any external agent laser light can be localized in a specific tissue region. On the other hand, laser parameters such as wavelength, fluence or irradiance, pulse duration, repetition rate, irradiation time and spot size can be adjusted to get successful tissue closure $[5,45,48]$. In the following sections optimization studies of any of these parameters will be introduced.

\subsection{Tissue closure and anastomosis by medical lasers}

Two types of tissue welding can be defined: Laser Welding and Laser Soldering. In order to hold together, target tissue is irradiated with laser application in laser welding method. In the second type of application, use of soldering materials and wavelength specific absorptive dyes can enhance tissue sealing with the selective heating of target tissue.

Photothermal interaction occurs in a way that, laser (photon) energy, applied directly to the tissue surface is converted to the heat energy by molecular vibration of tissue chromophores such as water, melanin, hemoglobin by absorption (Figure-7). The rate of heat generation 
depends on the rate of absorption of photons within the tissue [47]. Scattered light that is absorbed may cause heating outside the laser beam. Increase in temperature to a certain degrees causes structural changes (interdigitation) in tissue proteins such as collagen and fibrinogen, in a way that they can bond each other in their open sites at the cooling phase. can cause irreversible damage of the proteins of the tissue (Table-1). Thermal response of laser irradiated tissue have been examined in detail and modeled by Welch et al [47-51].

\section{Laser tissue welding is photothermal process}

INTERACTION OF RADIATION WITH MATTER

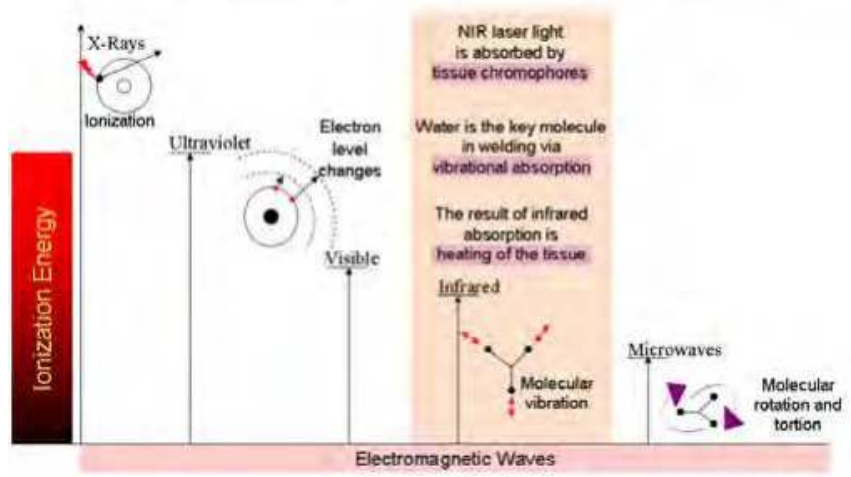

Fig. 7. Heating of tissue by infrared mediated molecular vibration.

\begin{tabular}{|cc|}
\hline Temperature & Molecular and Tissue Reactions \\
\hline $42-45^{\circ} \mathrm{C}$ & $\begin{array}{r}\text { Hyperthermia leading to protein st ructural changes } \\
\text { hydrogen bond breaking, retraction }\end{array}$ \\
\hline $45-500^{\circ} \mathrm{C}$ & $\begin{array}{c}\text { Enzyme inactivation } \\
\text { changes in membrane permeabilization, oedema }\end{array}$ \\
\hline $50-60^{\circ} \mathrm{C}$ & Coagulation, protein denaturation \\
\hline$\sim 80^{\circ} \mathrm{C}$ & Collagen denat uration \\
\hline $80-100^{\circ} \mathrm{C}$ & Dehydration \\
\hline $100^{\circ} \mathrm{C}$ & Boiling, steaming \\
\hline $100-300^{\circ} \mathrm{C}$ & Vaporization, tissue ablation \\
\hline $300^{\circ} \mathrm{C}$ & Carbonization \\
\hline
\end{tabular}

Table 1. Laser Tissue Interactions: Photothermal Effects [44]

Wide range of medical lasers has been used for laser tissue welding. Lasers mainly operate in infrared region such as carbon dioxide $\left(\mathrm{CO}_{2}\right)$, THC:YAG, Ho:YAG, Tm:YAG, and Nd:YAG, and gallium aluminum arsenide diode (GaAlAs) lasers are suitable for tissue welding [52-55]. The $\mathrm{CO}_{2}$ laser has been preffered repairing of thin tissues because of relatively short 
penetration depth (shorter than $20 \mu \mathrm{m}$ ) in tissue (Table-2). On the other hand, in thick tissues, high irradiances or long exposure times are necessary for sealing of target tissue [47]. Those types of applications cause undesired consequences such as carbonization of tissue and the conduction of heat from the initial absorption zone to surrounding tissue [45].

\begin{tabular}{|cccc|}
\hline Laser & $\lambda(\mathrm{nm})$ & $\delta_{\text {water }}[53,54]$ & $\delta_{\text {tissue }}[54,55]$ \\
\hline Argon ion & 488 & $23 \mathrm{~m}$ & $0.8 \mathrm{~mm}$ \\
KTP/Nd:YAG & 532 & $16 \mathrm{~m}$ & $1.1 \mathrm{~mm}$ \\
HeNe & 632.8 & $4.8 \mathrm{~m}$ & $3.5 \mathrm{~mm}$ \\
Ga.41As & 780 & $60 \mathrm{~cm}$ & $7 \mathrm{~mm}$ \\
& 820 & $46 \mathrm{~cm}$ & $8 \mathrm{~mm}$ \\
& 870 & $25 \mathrm{~cm}$ & $7 \mathrm{~mm}$ \\
Nd:YAG & 1064 & $4 \mathrm{~cm}$ & $4 \mathrm{~mm}$ \\
Nd:YAP & 1080 & $5 \mathrm{~cm}$ & $4 \mathrm{~mm}$ \\
Ho:YAG & 2100 & $0.2 \mathrm{~mm}$ & $1 \mathrm{~mm}$ \\
Er:YAG & 2940 & $1 \mu \mathrm{m}$ & $<1 \mu \mathrm{m}$ \\
CO $_{2}$ & 10600 & $10 \mu \mathrm{m}$ & $20 \mu \mathrm{m}$ \\
\hline
\end{tabular}

Table 2. Penetration Depths of Some Medical Lasers in Water and in Tissue

Temperature controlled laser systems have been developed to get rid of over-heating consequently thermal injury to the surrounding tissue. Researchers applied radiometric methods to determine the temperature of the surface of the heated cut and used computer assisted temperature feedback control to maintain tissue surface temperature at some desired level. The Applied Physics group at the Tel Aviv University developed a laser fiberoptic system for monitoring and controlling the temperature $[59,60]$ for $\mathrm{CO}_{2}$ laser welding and/or soldering. Polycrystalline silver halides (AgClxBr1-x), which are highly transparent in the mid-infrared spectral region ( 3 to $30 \mu \mathrm{m})$ used in optical fibers transmits emitting infrared radiation from surface of laser application spot to radiometric detector which is connected to the personal computer. The personal computer controls the power emitted by the laser, and thus temperature. The system has been tried in various kinds of tissues. Skin tissue closure in rabbits, wound healing pattern was observed on $3^{\text {rd }}, 7^{\text {th }}, 14^{\text {th }}$ and $28^{\text {th }}$ post operative days of healing period by Simhon et al. [61]. Laser application along incision was done spot by spot. The mean laser power density at the heated spots was 7 $\mathrm{W} / \mathrm{cm}^{2}$. The spot size was $3 \mathrm{~mm}$ in diameter on tissue surface. Histology examinations showed thermal injury, as basophilic coloring, necrosis or carbonization residues, the presence of surface albumin residues, and degree of re-epithelialization. Laser skin closure with thermal control was found to be more successful to other wound-closure modes. Thermal damage was minimized by the use of a temperature controlled fiber optic lasersoldering system. Tensile test performed as a complimentary for this study [62] revealed immediate tensile strength values that were similar to those obtained with cyanoacrylate glues. Moreover, laser-soldered incisions exhibited stronger long-term tensile strength and presented better wound healing behaviour, akin sutured incisions. 
In vivo study was also performed in porcine model by Simhon etal. [63] aiming toward clinical trials by evaluating the efficacy, reproducibility, and safety of the temperature controlled laser system procedure in pigs. $500 \mathrm{~mW} \mathrm{CO}$ laser power was applied to the skin tissue. Therefore, the optimal soldering temperature was found to be within the range of $65^{\circ} \mathrm{C}$ to $70^{\circ} \mathrm{C}$. At this range, successive tensile strength and tight sealing of the wound was accomplished.

The system has been tried also in soft tissue welding in different animals.

It was found that laser welded tissue has been much less scar tissue compared to control group (standard suture) at the end of 30-day inspection period [64]. Rat intestine argon laser (operates at multiple visible wavelengths from $488 \mathrm{~nm}$ to $515 \mathrm{~nm}$, irradiance was $28 \mathrm{~W} / \mathrm{cm} 2$ ) tissue fusion was carried out by Çilesiz et al. [65] found that laser-assisted intestinal anastomoses provided an immediate fluid-tight closure compared to the suture control anastomoses. Less thermal hazard were inspected when laser irradiation was controlled by thermal feedback. At 3 weeks, all anastomoses were mechanically as strong as intact intestine, although bursting/leaking pressure tests of laser-assisted anastomoses without thermal feedback control (TFC) tended to be lower than all sutured anastomoses (control) group and laser tissue welding with TFC group. Experimental findings indicated that; although welds were initially weak, they were sufficiently stabilized to resist spontaneous rupture in surviving animals. In similar study performed by Çilesiz et al., Ho:YAG $(2.09 \mu \mathrm{m}$, irradiance was $16 \mathrm{~W} / \mathrm{cm}^{2}$ ) laser was used to anastomose rat intestine with and without TFC at $90^{\circ} \mathrm{C}[66]$.

Simple and easy-to-apply methods are demanded in minimally invasive surgery. In a study performed by Spector et al. [67] small bowel harvested from 6-month-old pigs was successfully anastomosed by using albumin stent heated up by $828 \mathrm{~nm}$ GaAs semiconductor laser diode which emission was delivered to the tissue by $600 \mu \mathrm{m}$ silica fiber. Experimental setup was established such that the laser delivery fiber and the radiometer fiber was positioned $8 \mathrm{~mm}$ from the tissue, producing a $3.4 \mathrm{~mm}$ diameter spot with a maximal power density of $30 \mathrm{~W} / \mathrm{cm}^{2}$. Albumin stent laser anastomosis of bowel sustained statistically significant higher bursting pressures than those done by sutures. The addition of solder materials (blood, fibrinogen, and albumin) and wavelength specific chromophore help to strengthen the wound, to maintain edge alignment and to focus energy to the target region. Furthermore, due to the increased absorption characteristics of the dyed tissue or solder, low-level laser powers may be used to achieve the required effect, increasing the safety of the technique. The combination of serum albumin and ICG dye with an 800-nm diode laser has been tried in numerous of applications in order to nd optimal solder composition [6773].

One of the most comprehensive studies was performed by McNally et al [74] to investigate the relative importance of these parameters to laser tissue soldering. Twenty five different combinations of laser irradiance and exposure time were used. The effect of changing bovine serum albumin concentration and indocyanine green dye concentration of the protein solder on the tensile strength of the resulting bonds was investigated on ex vivo aorta specimens irradiated with $808 \mathrm{~nm}$ diode laser delivered $400 \mu \mathrm{m}$-core silica fiber. Spot size at the protein solder surface was $1 \mathrm{~mm}$. Mechanical test and electron microscopy analysis were performed in order to investigate bond stability in hydtarion point of view. It was observed 
that the failure mechanisms were of two kinds. The liquid protein solder broke into two halves, but each remained attached to the tissue. On the other hand, the solid protein solder, remained intact but detached from the tissue. The overall tensile strength of repairs formed using the solid protein solder were significantly higher than the strength of the liquid protein solder repairs was noted. Although achievements have come to a considerable point, technical problems should be overcome. Three disadvantages of the solid protein solder have been indicated [75]. First, a non-uniform solder coagulant generally results in because of temperature gradient over depth of the solder. Second, the protein solder is soluble. Third, the solid protein solder is not flexible enough to fit different tissue geometries. Specially designed artificial solder- doped PGA membranes were tried for laser tissue soldering by McNally et al. and Hodges et al. [69, 75]. The albumin protein solder and the polymer materials are biodegradable. This brings about the minimal foreign body reaction and infection. PLGA based synthetic materials were prepared. Average irradiances of 5.7, 11.3, and $17.0 \mathrm{~W} / \mathrm{cm}^{2}$ delivered to the solder surface [75]. Results showed that the solderdoped polymer membranes improved repair strength as well as exibility during application over previous published results with albumin protein solders. Moreover tissue apposition can be established by rehydration of the solder-doped polymer membranes upon application.

Lauto et al. examined in vitro and in vivo tissue repair with chitosan adhesive [76]. Chitosan gels have been shown to induce no thermal damage to tissue and to produce better sealing [77]. Chitosan adhesives provide manipulation of tissue without breaking or tearing. The adhesive can be hold when manipulated with forceps and appeared to be well suited for tissue repair A review paper about different tissue reconstruction strategies employing adhesive biomaterials currently used in surgical and experimental procedures was written by Lauto PhD. concluded that each of these adhesives has an optimal clinical application depending on its physical-chemical characteristics (adhesiveness, fluid or solid consistency, chemical or light activation for example). It is thus very likely that different bioglues will be adopted by surgeons for their specific operative procedures, instead of a single product [78].

\section{Materials and methods}

\subsection{Surgical applications}

All experiments were performed under authorization of Institutional Animal Research and Care Ethic Committee at Boğaziçi University (BUHAYDEK, Date:1/12/2005, No:2005-6). Male Wistar Rats, randomly selected, 7-9 months old, weighing 290-320 g, from Psychobiology Laboratory of Boğaziçi University were used in all experiments mentioned in this study. Rats were housed in plastic cages and maintained on a 12-h-light/12-h-dark cycle in a temperature-controlled vivarium $\left(22 \pm 2^{\circ} \mathrm{C}\right)$. Food and water were available ad libitum.

\section{Surgery}

Wistar rats were anesthetized with ketamine (10\% ketamidor, RichterPharma, AG, Wels, Austria) by intraperitoneal injection $(1.65 \mathrm{ml} / \mathrm{kg})$. Hair at the site of application was shaved. Antiseptic Poviiodex Scrub (Kim-Pa İlaç Lab. Inc. Hadımköy) was applied topically to prevent infection and desiccation of the wounds. Three pairs of 1-cm-long full-thickness incisions (over muscular layer), bilateral and parallel to the spinal cord, were done. Incisions were implemented with sterile No.11 surgical blade (Tontarra Medizintechnik GMBH, Germany). In 
case of bleeding, incision site was compressed and any blood remnant was cleaned from top of skin in order to prevent probable light absorption by blood remnant on the surface of skin rather than skin tissue itself. Incision was closed with near infrared lasers (either $809 \mathrm{~nm}, 980$ $\mathrm{nm}$ or $1070 \mathrm{~nm}$ ) or suturing that was used as control group if included in any of experiment.

\section{Post Surgery}

After closure, Thiocilline (Abdi İbrahim İlaç Inc., İstanbul, Turkey) was applied on each incision to inhibit any kind of microbial reactions on incisions. The length and the thickness of the incisions were checked via digital caliper (Mitutoyo, UK). No food or water was given 24-h post-surgery. Investigation of healing was performed through 4-day period for predosimetry studies and 21-day for comparative studies. 1st, 4th, 7th, 14th and 21st days were selected as control days during healing period. On these particular days, skin samples, closed either by NIR lasers or suture were collected for histology or tensile testing. During healing period, each rat was kept in separate cage until histology examination or tensile test on particular post operative days. At the end of the any experiment mentioned rats were anesthetized first and then killed (cervical dislocation).

\subsection{Closure methods: Laser systems and suturing}

\section{9-nm diode laser system}

The 809-nm Diode Laser System have been designed and improved in Boğaziçi University, Institute of Biomedical Engineering, Biophotonics Laboratory [79]. The system is a computer controlled high power $809-\mathrm{nm}$ laser (10 W output power at $35 \mathrm{~A}$ applied current). User interface was developed in $\mathrm{C}$ programming language communicates with the controller unit of the diode laser system to set the operating parameters of the diode laser module [80]. Laser output ber was coupled with $400 \mathrm{~nm}$ fiber via FC (Fixed Connection) connector to transfer laser energy to the target tissue part.

\section{0-nm diode laser system}

The 980-nm diode (OPC-D010-980-FCPS, Opto Power, Tuscon, AZ, USA) class IV laser was controlled by a microcontroller-based controller instrument, which was designed and manufactured by our group at Biophotonics Laboratory at Institute of Biomedical Engineering, Boğaziçi University [81]. The laser unit can also be controlled using OPC remote control module provided with the system. Either control device attaches to the laser system via the 25-pin D-sub connector on the front panel. In general description, high power diode laser system has $10 \mathrm{~W}$ maximum optical output. The system provides output through a 1 meter fiber-optic cable. Laser was delivered to the target tissue with a $400 \mu \mathrm{m}$ optical fiber (Spindler-Hoyer, Gottingen, Germany) via subMiniature version A (SMA) connection. The parameters (power, exposure time, number of cycles, and on-off duration of pulses) of the laser were controlled with interface developed in LabView software (V 6.1).

\section{0-nm Ytterbium fiber laser}

Device produced by IPG Laser $\mathrm{GmbH}$ and produces 20 Watts of optical power at a wavelength of $1070 \mathrm{~nm}$ (YLM-20-SC Series, Germany). In order to set number of pulses, power and exposure time, an external microcontroller based controller (Teknofil Inc., Istanbul, Turkey) was designed and used in experiments 


\section{Laser delivery}

Laser closure was performed that six spots were applied by a handpiece made up of plexiglass material at a distance of $2 \mathrm{~mm}$ above 1-cm long incision (Figure 8). Each spot had a $2 \mathrm{~mm}$ diameter and they slightly overlapped onto each other. Five seconds cooling time interval was given between spots. Spot size $\left(0.0314 \mathrm{~cm}^{2}\right)$ was checked with a detection card (VRC4, Thorlabs, NJ, USA) and power of the laser was checked with a powermeter (Newport 1918-C, CA, USA) before each application.

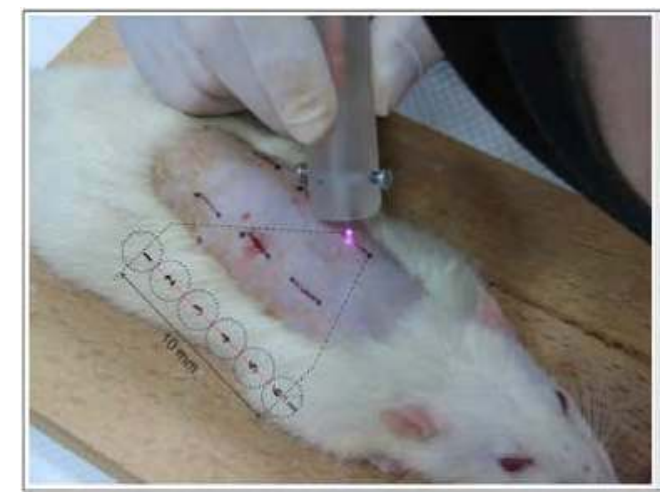

Fig. 8.6 laser spots along $1 \mathrm{~cm}$ incision. $2 \mathrm{~mm}$ spot size was obtained from optic fiber that was placed $2 \mathrm{~mm}$ above skin surface.

\section{Suturing}

A single, interrupted suture USP-3/0 metric silk (Doğsan Tibbi Malzeme San. A.Ş. TrabzonTurkey) was placed in the middle of the $1 \mathrm{~cm}$ long incisions. Distance between needle entrances to the tissue was about $10 \mathrm{~mm}$.

\subsection{Histology examinations}

Incision sites were removed one by one, in rectangular shape $(1 \times 2 \mathrm{~cm})$ from rat's dorsal skin and stored in tissue fixative (10\%PBS formaldehyde) until tissue processing that was automatically performed by tissue processing machine (LeicaTP-1020, Germany). Paraffin embedding and tissue sectioning were performed. Hematoxylin and Eosin (H\&E) staining was used for histological examinations. This stain gives idea about general tissue structure. Hematoxylin, a basic dye, stains nuclei blue due to an affinity to nucleic acids in the cell nucleus; eosin, an acidic dye, stains the cytoplasm, reticular and elastic fibers pink.

\subsection{Image analysis}

Histology samples were examined under light microscope (Eclipse 80i,Nikon Co., Japan) and high resolution (2560x1920 pixel) images were taken with 5 megapixel CCD camera (DS-Fi1, Nikon Co., Japan) either one of the techniques: brightfield light, polarized light and phase contrast condenser, to determine thermal effect of near infrared lasers to the tissue as well as tissue closure abilities. Imaging software (NIS Elements-D, NikonCo., Japan) was used to quantify parameters which give idea on how successfully an incision closed. 
Mentioned parameters are: Closure Index (CI) (Figure 9), Thermally Altered Area (TAA) (Figure 10), Granulation Area (GA) and Epidermal Thickness (ET).

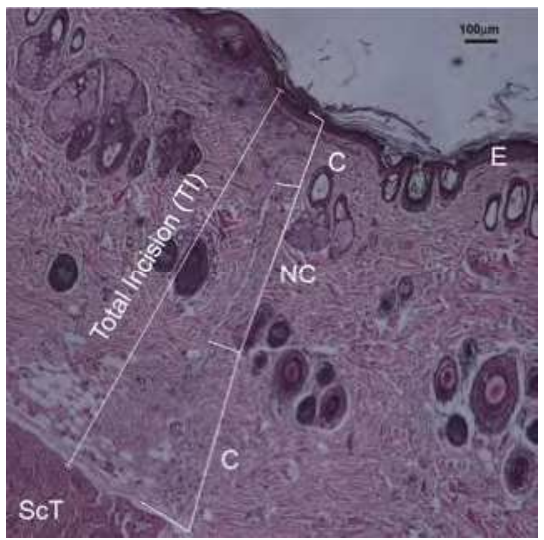

Fig. 9. Computation of Closure Index. C: Closed, NC: Non-closed, E: Epidermis, ScT: Subcutaneous tissue, TI: Total Incision. X4, H\&E, Brightfield.

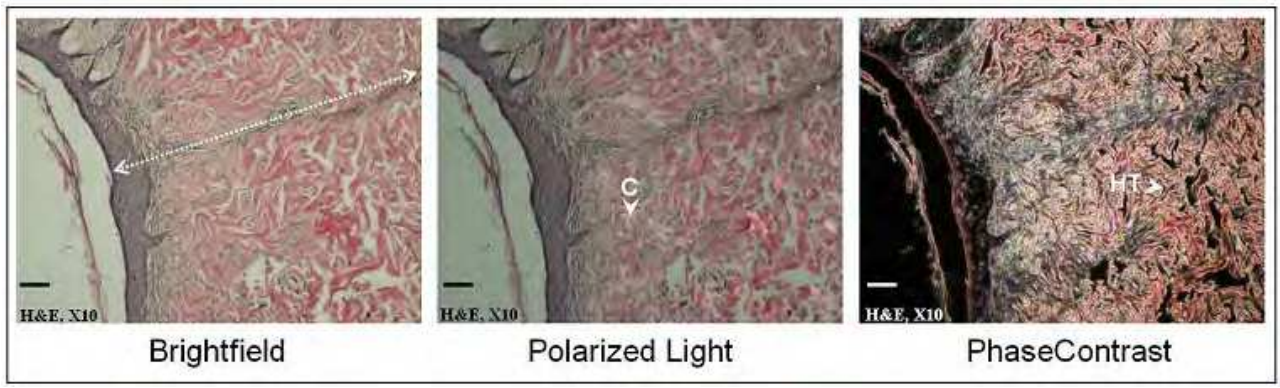

Fig. 10. Assessment of thermally altered areas (TAA). Image examined with bright field, polarized light and phase contrast microscopy is same. The bright-field microscopy reveals overall structure soft tissue sample. Incision line was indicated by arrow. The polarized microscopy reveals the collagen molecules (C) that were not affected by heat. Denatured collagen molecules loose their birefringent characteristic. The phase contrast technique reveals the hyperthermal (HT) area. H\&E, X10, ScaleBar is $100 \mu \mathrm{m}$.

\subsection{Tensile test}

Dumbbell-shaped stripes, including incision site, was removed. In order to minimize drying, tensile strength tests were performed in between 10 minutes after removal. Samples were placed between single column universal testing machine (LF Plus, Lloyd Instruments, UK) jigs' such a way that grips (TG34, Lloyd Instruments, UK) were as close as possible (2-4 $\mathrm{mm})$. Jigs surfaces were notched like lock-and-key to prevent skin sample slipped through jigs. Each sample was tested at $5 \mathrm{~mm} / \mathrm{min}$ crosshead velocity. Force (N) and time (s) at break point (this was determined as first opening anywhere along $1 \mathrm{~cm}$ long incision) were recorded by software Nexygen Plus. 


\section{Results and discussion}

Laser tissue soldering (LTS) using a diode laser and an indocyanine green (ICG)/albumin solder has been shown to be an effective technique by providing watertight sealant with minimal damage to underlying tissue [82, 83]. Cooper et al. [83] tried power densities of 3.2, 8, $15.9,23.9,31.8,47.7$, and $63.7 \mathrm{~W} / \mathrm{cm}^{2}$ at constant ICG concentration $(2.5 \mathrm{mg} / \mathrm{ml}) .15 .9 \mathrm{~W} / \mathrm{cm}^{2}$ power density was found providing the most controlled heating curve. At a power density of $15.9 \mathrm{~W} / \mathrm{cm}^{2}$ or below, increasing ICG concentrations did appear to result in small, but significant, increases in immediate tensile strength as well. $15.92 \mathrm{~W} / \mathrm{cm}^{2}$ power density showed the optimal result in our study in a different aspect: thermal quantitative measurements. Results favoured the $15.92 \mathrm{~W} / \mathrm{cm}^{2}$ power density in laser skin tissue soldering by giving less thermal damage and higher closure rate. On the contrary, the results of the optimal parameter investigation performed by McNally et al. Suggest that the strongest repairs are produced with lower irradiances of around $6.4 \mathrm{~W} / \mathrm{cm}^{2}$ after approximately 50 seconds exposure time by using a solid protein solder composed of $60 \%$ BSA and $0.25 \mathrm{mg} / \mathrm{ml} \mathrm{ICG} \mathrm{on} \mathrm{ex} \mathrm{vivo} \mathrm{aorta} \mathrm{specimens} \mathrm{[74].}$ Another in vivo study performed by Capon et al. [43] on mutant OFA Sprague-Dawley rats skin incisions closed over transparent adhesive dressing (Tegaderm, 3M Health Care, Borken, Germany) with the following parameters: $815 \mathrm{~nm}$ diode laser, $1.5 \mathrm{~W} ; 3$ seconds; spotdiameter: 2 $\mathrm{mm}$; fluence: $145 \mathrm{~J} / \mathrm{cm}^{2}$. The parameters used in this study lead to a slow temperature increase upto a plateau below the critical coagulation temperature $\left(53^{\circ} \mathrm{C}-60^{\circ} \mathrm{C}\right)$, avoiding thermal damage [49]. The optimal irradiance $\left(47 \mathrm{~W} / \mathrm{cm}^{2}\right)$ used in this study seems to be very similar to the value reported by Abergel et al. [84] $\left(50 \mathrm{~W} / \mathrm{cm}^{2}\right)$. Three times higher laser irradiance was applied for effective skin closure compared to current study without any thermal damage. High irradiation was avoided by use of ICG and use of albumin supplied good apposition for tissue closure.

\subsection{Closure index}

Laser welding techniques aims immediate healthy tissue closure. So, histological examination in the very early steps of recovery period revealed succes of this technique. (Figure 11).

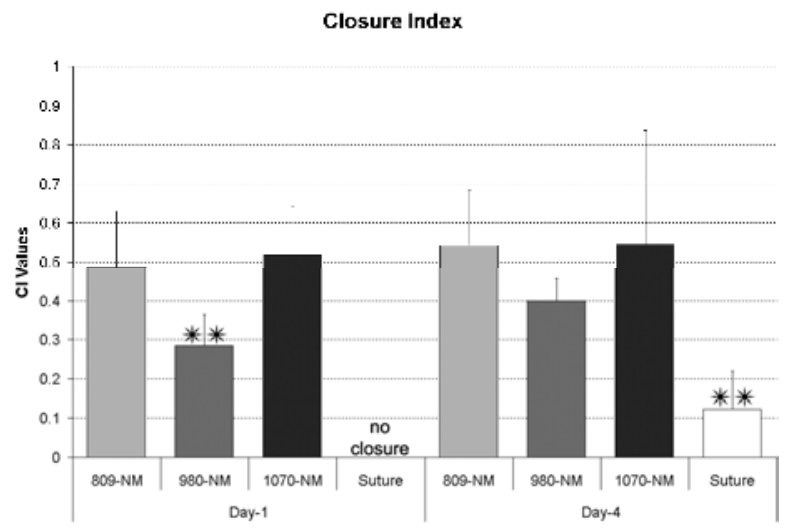

Fig. 11. Closure index values of $809 \mathrm{~nm}, 980 \mathrm{~nm}$, and $1070 \mathrm{~nm}$ laser irradiated and sutured incisions. CI is the ratio of closed segment to total incision (from skin surface to subcutaneous layer). On day 1: immediate closing of laser groups, sutured incisions remained open [85]. 


\subsection{Thermally altered areas}

Thermal effects such as hyperthermia and coagulation around laser irradiated area was monitored and quantified (Figure 12).

\subsection{Granulation tissue area and epidermal thickness}

Granulation tissue had started to form on the 4th postoperative day only in the $809 \mathrm{~nm}$ and $1070 \mathrm{~nm}$ irradiated samples. Granulation tissue measurement on day 21 showed no statistical difference between experimental groups.

Epidermal thickness (ET) normally starts at a higher value and gradually decreases to a certain level, depending on the degree of the trauma. On day 21, the epidermal thicknesses of all groups' incisions showed no statistical difference and were around the 35-40 $\mu \mathrm{m}$ level $(p<0.05)$. The most impressive results for epidermal thickness were obtained from the 1070 $\mathrm{nm}$ laser irradiated samples: there was almost no thickening ( $35 \mu \mathrm{m}$ following the operation and during the 21-day recovery period.

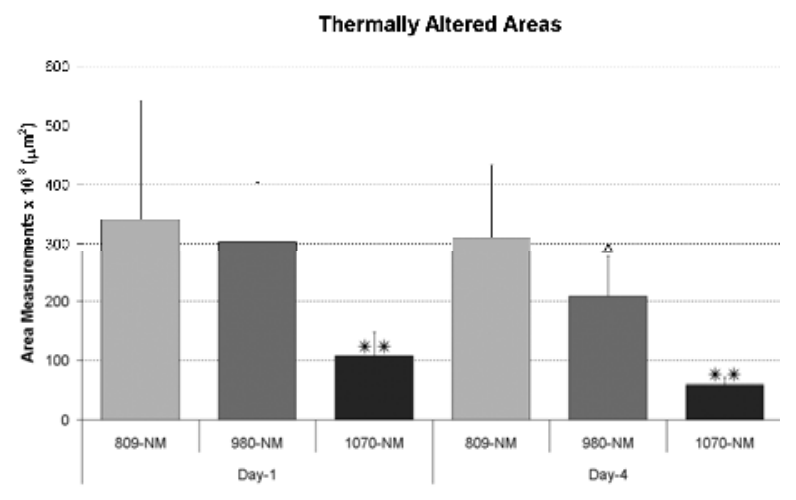

Fig. 12. The thermal hazard of $1070 \mathrm{~nm}$ laser welding was minimum on day 1 and on day 4 $(\mathrm{p}<0.05)$. Soldering (ICG+BSA) with the $809 \mathrm{~nm}$ diode laser was the most thermally hazardous of all the lasers on day $4(\mathrm{p}<0.05)$. No tissue carbonization was observed in any of the applications [85]. 


\subsection{Tensile tests}

Overall tensile strengths are shown in Figure 13. Measurement was not applicable for sutured incisions on day 1 (the incisions had not closed).

Tensile Test

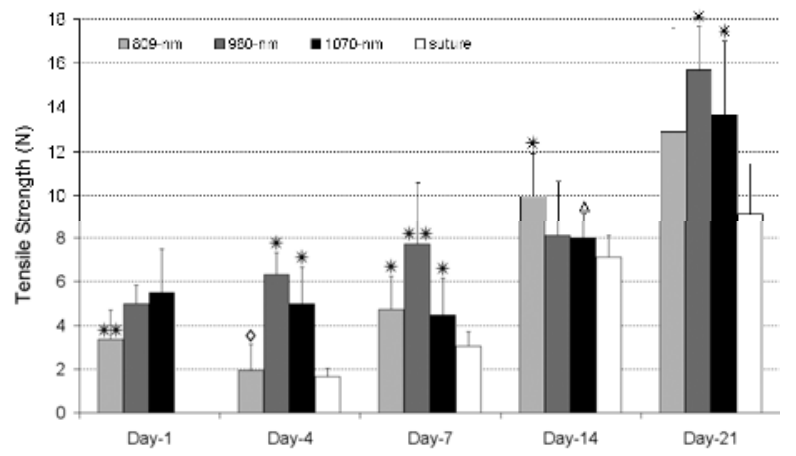

Fig. 13. Mechanical (tensile) test results. On day 1, the tensile strengths of the $809 \mathrm{~nm}$ closed incisions were weaker than those of the welded incisions $\left(^{* *}\right)(p<0.05)$. On day 21 , tensile strengths of the laser-welded incisions $(980 \mathrm{~nm}$ and $1070 \mathrm{~nm})$ were greater than in the control group $\left(^{*}\right)(\mathrm{p}<0.05)$ [85].

\section{Conclusion}

This study is a comprehensive comparative research which has accomplished the following tasks:

1. Comparison of laser welding and suturing methods on a surgical skin incision

Two closure methodologies served a physical approximation for edges of incision. Laser energy went one step further and managed to seal the gap leakproof. No redness which is a sign of pus formation was observed macroscopically in any of the incision closed with either lasers. Tensile strength gained at the end of the rst week of healing period for suture closed incisions had been already achieved in 24 hours post surgery by laser welding. At the end of 21-Days follow up of recovery period, tensile strengths of laser-welded incisions were greater than in the control group. This shows that laser welding is advantageous over suturing.

2. Comparison of effects of different wavelengths on skin tissue welding

Three near infrared wavelengths $(809,980$ and $1070 \mathrm{~nm})$ were compared and found to have different welding abilities. Each of these wavelengths should be chosen for specific welding purpose. For instance, any incision on face can be closed by $1070 \mathrm{~nm}$ laser for aesthetic appearance whereas strong closure in skin tissue over joints can be obtained by $980 \mathrm{~nm}$ laser application.

3. Establishment of experimental protocols and measurement techniques

Full-thickness incisions were done through skin tissue. Laser applications were done precisely spot by spot having cooling time intervals in between. Changes in tissue structure 
were observed by general staining method combined with special microscopy techniques. Macroscopic and microscopic inspections were quantified, resulting in new terminology for future studies: Closure Index, Thermally Altered Area, Granulation Area, and Epidermal Thickness. All the mentioned inspections were performed on particular days at given period of surgical incision healing. Progress of bonding was measured as tensile strength through the same particular days, thus histological findings were evaluated from mechanical point of view or vice versa.

\section{Acknowledgment}

The authors are grateful for the grant support provided by The Scientific \& Technological Research Council of Turkey - TÜBITTAK, contract number, 104M428 and 107E119, and Boğaziçi University Research Fund (contact number: BAP-06M102) The rats were obtained from the Psychobiology Laboratory (Dr.ReşitCanbeyli), BoğaziçiUniversity. The $980 \mathrm{~nm}$ diode laser was provided by Dr. İnci Çilesiz, İstanbul Technical University.

\section{References}

[1] Niemz M H (1996) Laser Tissue Interactions: Fundementals and Applications, Springer. $297 \mathrm{p}$.

[2] Gürkan Özer A (2008) Comparative Temperature Measurements on Brain and Liver Tissues Using $1070 \mathrm{~nm}$ LASER. MSc Dissertation. İstanbul Technical University. $124 \mathrm{p}$.

[3] Prasad P N (2003) Introduction to Biophotonics. Wiley-Interscience. 593 p.

[4] Yahr W Z, Strully K J (1964) Non-occlusive small arterial anastomosis with neodymium laser. Surg Forum. 15: 224.

[5] McNally-Heintzelman K M, Welch A J (2003) Laser tissue welding. In Tuan V D editor. Biomedical Photonics Handbook. New York: CRC Press LLC. pp. 39(1)-39(45),

[6] Schober R, Ulrich F, Sander T, Durselen H, Hessel S (1986) Laser-induced alteration of collagen substructure allows microsurgical tissue welding. Science. 232: 1421-1422.

[7] Tang J. Godlewski G, Rouy S, Delacretaz G (1997) Morphologic changes in collagen fibers after $830 \mathrm{~nm}$ diode laser welding. Lasers Surg Med. 21-4: 438-443

[8] Bass L S, Moazami N, Pocsidio J, (1992) Changes in Type-I collagen following laser welding. Lasers Surg Med. 12: 500-505.

[9] Vale B H, Frenkel A, Trenka-Benthin S (1986) Microsurgical anastomosis of rat carotid arteries with the $\mathrm{CO}_{2}$ laser. Plast Reconstr Surg. 77: 759-766.

[10] Menovsky T, Beek J F, Van Gemert M J C (1996) Laser tissue welding of dura mater and peripheral nerves: A scanning electron microscopy study. Lasers Surg Med. 19: 152158.

[11] Godlewski G, Rouy S, Dauzat M (1987) Ultrastructural study of arterial wall repaira after argon laser microanastomosis Lasers Surg Med. 7: 258-262.

[12] Kopchock G E (1988) Mechanism of tissue fusion in argon laser-welded vein artery anastomoses. Lasers Surg Med. 83-89.

[13] Kada O, Shimizu K, (1987) An alternative method of vascular anastomosis by laser: Experimental and clinical study. Lasers Surg Med. 7: 240-248. 
[14] Constantinescu M A, Alferi A, Mihalache G, Stuker F, Ducray A, Seiler R W (2007) Effect of laser soldering irradiation on covalent bonds of pure collagen. Lasers Med Sci. 22: 10-14.

[15] Mustoe T A, Pierce G F, Thomason A, Gramates P, Sporn M B, Deuel T F (1987) Accelerated healing of incisional wounds in rats induced by transforming growth factor. Science 237-4820: 1333-1336.

[16] Stadelmann W K, Digenis A G, Tobin G R (1998) Physiology and healing dynamics of chronic cutaneous wounds. Am J Surg (Suppl 2A) 176: 26S-38.

[17] Ross R, Benditt E. P (1962) Wound healing and collagen formation: Fine structure in experimental scurvy. J. Cell Biol. 12: 533-551.

[18] Williamson D, Harding K (2004) Wound healing. Medicine. 32-12: 4-7.

[19] Lindstedt E, Sandblom P (1975) Wound healing in man: Tensile strength of healing wounds in some patient groups. Ann. Surg. 181- 6: 842-846.

[20] Ordman L J, Gillman T (1966) Studies in the healing of cutaneous wounds. Arch Surg. 93-6: 857-882.

[21] Prockop D, (1998) What holds us together? Why do some of us fail apart? What can we do about it? Matrix Biology. 16: 519-528.

[22] Hochberg J, Meyer K M, Marion M D (2009) Suture choice and other methods of skin closure. Surg Clin N Am. 89: 627-641.

[23] Quinn J, Maw J, Ramotar K, Wenckebach G, Wells G (1997) Octylcyanoacrylate tissue adhesive versus suture wound repair in a contaminated wound model. J. Vasc. Surg. 122-1: 69-72.

[24] Quinn J, Wells G, Sutcliffe T, Jarmuske M, Maw J, Stiell I, Johns P (1998) Tissue adhesive versus suture wound repair at 1 year: Randomized clinical trial correlating early, 3month, and 1-year cosmetic outcome. Annals of Emergency Medicine. 32-6: 645649.

[25] Leaper D J, Pollock A V, Evans M (2005) Abdominal wound closure: A trial of nylon, polyglycolic acid and steel sutures. British Journal of Surgery. 64-8: 603-606.

[26] Barnett P, Jarman F. C, Goodge J, Silk G, Aickin R (1998) Randomised trial of histoacryl blue tissue adhesive glue versus suturing in the repair of paediatric lacerations. J.Paediatr. Child Health. 34-8: 548-550.

[27] Hollander J, Singer A. J (1998) Application of tissue adhesives: Rapid attainment of proficiency. Academic Emergency Medicine. 5-10: 1012-1017.

[28] Agarwal A, Kumar D, Jacob S, Baid C, Agarwal A, Srinivasan S (2008) Fibrin glue assisted sutureless posterior chamber intraocular lens implantation in eyes with deficient posterior capsules. J. Cat Ref .Surg. 34-9: 1433-1438.

[29] Babetty Z, Sumer A, Altintas S (1998) Knot properties of alternating sliding knots with different patterns in comparison to alternating and simple sliding knots. J.Am Coll Surg. 186-5: 485-489.

[30] Babetty Z, Sumer A, Altintas S, Erguney S, Goksel S (1998) Changes in knot holding capacity of sliding knots in vivo and tissue reaction. Arch Surg. 133: 727-734.

[31] Altman G H, Diaz F, Jakuba C, Calabro T, Horan R L, Chen J, Lu H, Richmond J, Kaplan L (2003) Silk based biomaterials. Biomaterials. 24- 3: 401-416.

[32] Parell G J, Becker G D (2003) Comparison of absorbable with nonabsorbable sutures in closure of facial skin wounds. Arch Facial Plast Surg. 5: 488-490. 
[33] Austin P E, Dunn K A, Cofield K E, Brown C K, Wooden W A, Bradfield J. F (1995) Subcuticular sutures and the rate of inflammation in noncontaminated wounds. Ann Emerg Med. 25-3: 328-330.

[34] Moy R L, Waldman B, Hein D W (1992) A review of sutures and suturing techniques. J. Dermatol. Surg.Oncol. 18: 785-795.

[35] Bass L, Treat M (1995) Laser tissue welding: A comprehensive review of current andfuture clinical applications. Lasers Surg Med 17: 315-349.

[36] Barrerias D, Reddy P P, McLorie G A, Bagli D, Khoury A E, Farhat W, Lilge L, Merguerian P A (2000) Lessons learned from laser tissue soldering and fibrin glue pyelo-plasty in an in vivo porcine model. J. Urol. 164-3: 1106.

[37] Wolf J S, Soble J J, Nakada S Y, Rayala H J, Humphrey P A, Clayman R V,. Poppas D P (1997) Comparison of brin glue, laser weld, and mecanical suturing device for laparoscopic closure of ureterotomy in a porcine model. J.Urol. 157-4: 1487.

[38] Zhang L, Kolker A R, Choe E I, Bakshandeh N, Josephson G, Wu F C, Siebert J W, Kasabian A K (1997) Venous microanastomosis with unilink system, sleeve, and suture techniques: A comparative study in the rat. J. Reconst.Microsurg. 13-4: 257.

[39] Pursifull N F, Morey A F (2007) Tissue glues and nonsuturing techniques. Current Opinionin Urology. 17- 6: 396-401.

[40] Durham L H, Willatt D J, Yung M W, Jones I, Stevenson P A, Ramadan M F (1987) A method for preparation of fibrin glue. J. Laryn. Otol. 101: 1182- 1186.

[41] Godlewski G S, (1995) Scanning electron microscopy of microarterial anastomoses with a diode laser: Comparisonwith conventional manual suture. J.Reconstr. Microsurg. 11-1: 33-40.

[42] Hasegawa M, Sakurai T, Matsushita M, Nishikimi N (2001) Comparison of argon-laser welded and sutured repair of inferior vena cava in canine model. Lasers Surg Med. 29-1: 60-68.

[43] Capon A, Souil E, Gauthier B, Sumian C, Bachelet M, Buys B, Polla B S, Mordon S (2001) Laser assisted skin closure (LASC) by using a 815-nm diode-laser system accelerates and improves wound healing. Lasers Surg Med. 28: 168-175.

[44] Chikamatsu E, Sakurai T, Nishikimi N, Yano T, Nimura Y (1995) Comparison of laser vascular welding, interrupted stures, and continuous sutures in growing vascular anastomoses. Lasers Surg Med. 16-1: 32-41.

[45] Çilesiz I F, Thermal Feedback Control During Laser-Assisted Tissue Welding. PhD thesis, The University of Texas at Austin, Texas, USA, 1994.

[46] McNally K M, Dawes J M, Parker A E, Lauto A, Piper J A, Owen E R (1999) Laseractivated solid protein solder for nerve repair: In vitro studies of tensile strength and solder/tissue temperature. Lasers Med Sci. 14: 228-237.

[47] Welch A J, Torres J H, Cheong W F (1989) Laser physics and laser-tissue interaction Texas Heart Inst J. 16: 141-149.

[48] Welch A J, van Gemert M J C, Star W, Wilson B (1995) Optical-Thermal Response of Laser-IrradiatedTissue. New York: Plenum Press.

[49] Welch A J (1984) The thermal response of laser irradiated tissue. IEEE J Quantum Electron. QE-20-12: 1471-1481.

[50] Chen B, Thomsen S L, Thomas R J, Oliver J, Welch A J (2008) Histological and modeling study of skin thermal injury to $2.0^{1} \mathrm{~m}$ laser irradiation. Laser Surg Med. 40: 358-370. 
[51] Springer T A, Welch A J (1993) Temperature control during laser vessel welding. Appl Opt. 32-4: 517-525.

[52] Oz M C, Bass L S, Popp H W, Chuck R S, Johnson J P, Trokel S L, M R Treat (1989) In vitro comparison of thulium-holmium-chromium:YAG and argon ion lasers for welding biliary tissue. Lasers Surg Med. 9-3: 245-252.

[53] Menovsky T, Beek J F, van Gemert M J C (1994) $\mathrm{CO}_{2}$ laser nerve welding: Optimal laser parameters and the use of solders in vitro. Microsurgery. 15-1: 44-49.

[54] Brooks S G, Ashley S, Fisher J, Davies G A, Griths J, Kester R C, Rees M R (1992) Exogenous chromophores for the argon and Nd:YAG lasers: A potential application to laser-tissue interactions. Lasers Surg Med. 12: 294-301.

[55] Fried N M, Walsh T (2000) Laser skin welding: In vivo tensile strength and wound healing results. Lasers Surg Med. 27-1: 55-63.

[56] Optical constants of ice from the ultraviolet to the microwave http:/ / omlc.ogi.edu/spectra/water/data/warren95.dat. Accessed 2012 Feb 16.

[57] Walsh J T, Flotte T J, Deutsch T F (1989) Er:YAG laser ablation of tissue: E$\leftarrow$ ect of pulse duration and tissue type on thermal damage. Lasers Surg Med. 9: 314-326.

[58] Van Gemert M J C, Welch A J (1989) Clinical use of laser-tissue interactions (1989) IEEE Eng Med Biol Mag. December: 10-13.

[59] Simhon D, Ravid A, Halpern M, Çilesiz I, Brosh T, Kariv N, Leviav A, Katzir A (2001) Laser soldering of rat skin, using fiberoptic temperature controlled system Lasers Surg Med. 29-2: 265-273.

[60] Eyal O, Katzir A (1994) Thermal feedback control techniques for transistor-transistor logic triggered $\mathrm{CO} 2$ laser used for irradiation of biological tissue utilizing infrared fiber optic radiometry. Appl Opt. 33- 9: 1751-1754.

[61] Simhon D, Brosh T, Halpern M, Ravid A, Vasilyev T, Kariv N, Katzir A, Nevo Z (2004) Closure of skin incisions in rabbits by laser soldering I: Wound healing pattern. Lasers Surg Med. 35: 1-11.

[62] Brosh T, Simhon D, Halpern M, Ravid A, Vasilyev T, Kariv N, Nevo Z, Katzir A (2004) Closure of skin incisions in rabbits by laser soldering-II: Tensile strength. Lasers Surg Med. 35: 12:17.

[63] Simhon D, Halpern M, Brosh T, Vasilyev T, Ravid A, Tennenbaum T, Nevo Z, Katzir A (2007) Immediate tight sealing of skin incisions using an innovative temperaturecontrolled laser soldering device in vivo study in porcine skin. Anals of Surgery. 245-2: 206-213.

[64] Lobel B, Eyal O, Kariv N, Katzir A (2000) Temperature controlled $\mathrm{CO}_{2}$ laser welding of soft tissues: Urinary bladder welding in di $\leftarrow$ erent animal models (rats, rabbits, and cats). Lasers Surg Med. 26: 4-12.

[65] Çilesiz I, Thomsen S, Welch A J (1997) Controlled temperature tissue fusion: Argon laser welding of rat intestine in vivo, Part one. Lasers Surg Med. 21: 269-277.

[66] Çilesiz I, Thomsen S, Welch A J, Chan E K (1997) Controlled temperature tissue fusion: Ho:YAG laser welding of rat intestine in vivo, Part two. Lasers Surg Med. 21: 278286.

[67] Spector D, Rabi Y, Vasserman I, Hardy A, Klausner J, Rabau M, Katzir A (2009) In vitro large diameter bowel anastomosis using a temperature controlled laser tissue soldering system and albumin stent. Lasers Surg Med. 41: 504-508. 
[68] Lauto A, Trickett R, Malik R, Dawes J, Owen E (1997) Laser activated solid protein bands for peripheral nerve repair: An in vivo study. Laser Surg Med. 21: 134-141.

[69] Hodges D E, McNally K M, Welch A J (2001) Surgical adhesives for laser-assisted wound closure. Journal of Biomedical Optics. 6-4: 427-431.

[70] Chivers R A (2000) In vitro tissue welding using albumin solder: bond strengths and bonding temperatures. Int. J. Adhesion Adhesives. 20: 179-187.

[71] Fujita M, Morimoto Y, Ohmori S, Usami N, Arai T, Maehara T, Kikuchi M (2003) Preliminary study of laser welding for aortic dissection in a porcine model using a diode laser with indocyanine green. Lasers Surg Med. 32: 341:345.

[72] Birch J F, D J Mandley, S L Williams, D R Worrall, P J Trotter, F Wilkinson, P R Bell (2000) Methylene blue based protein solder for vascular anastomoses: An in vitro burst pressure study. Lasers Surg Med. 23: 323-329.

[73] Oz M C, S Prangi, R S Chuck, C C Marboe, L S Bass, R Nowygrod, M R Treat (1990) Tissue soldering by use of indocyanine green dye-enhanced fibrinogen with the near infrared diode laser. J Vasc Surg. 5: 718-725.

[74] McNally K M, B S Sorg E K Chan, A J Welch, J M Dawes, E R Owen (1999) Optimal parameters for laser tissue soldering. Part-I: Tensile strength and scanning electron microscopy analysis. Lasers Surg Med. 24: 319-331.

[75] McNally K M, B S Sorg A J Welch (2000) Novel solid protein solder designs for laserassisted tissue repair. Lasers Surg Med. 27: 147-157.

[76] Lauto A, M Stoodley, A Avolio, M Sarris, G McKenzie, D D Sampson, L J R Foster (2007) In vitro and in vivo tissue repair with laser-activated chitosan adhesive. Laser Surg Med. 39: 19-27.

[77] Ishihara M, K Nakanishi, K Ono, M Sato, M Kikuci, Y Saito, H Yura, T Matsui, H Hattori, M Uenoyama, A Kurita (2002) Photocrosslinkable chitosan as a dressing for wound occlusion and accelerator in healing process. Biomaterials. 23: 833-840.

[78] Lauto A, D Mawad, L J R Foster (2008) Review adhesive biomaterials for tissue reconstruction. J Chem Technol Biotechnol 83: 464-472.

[79] Geldi C, (2003) Microcontroller based high power 809-nm diode laser design for photodynamic therapy (PDT) applications. Master's Thesis, Boğaziçi University, Istanbul, Turkey.

[80] Geldi C, O Bozkulak, H O Tabakoğlu, S Isci, A Kurt, M Gulsoy (2006) Development of a surgical diode-laser system: Controlling the mode of operation. Photomed and Laser Surg. 24-6: 733-739.

[81] Geldi C, O Bozkulak, H O Tabakoğlu, S Isci, O Kalkanci, A Kurt, M Gülsoy (2004) Microcontroller based surgical diode laser system. Annual national meeting of biomedical engineers. 24: 44-47.

[82] Kirsch A J, M I Miller, T W Hensle, D T Chang, R Shabsigh, C A Olsson, J P Connor (1995) Laser tissue soldering in urinary tract reconstruction: First human experience. Urology. 46-2: 261-266.

[83] Kirsch A J, G M DeVries, D T Chang, C A Olsson, J P Connor, T W Hensle (1996) Hypospadias repair by laser tissue soldering: Intraoperative results and follow up in 30 children. Urology. 48: 616-623. 
[84] Abergel R P, R F Lyons, R A White, G Lask, L Y Matsuoka, R M Dwyer, J Uitto, C A Torrance, I L Springfield. Skin closure by Nd:YAG laser welding. J Am Acad Dermatol. 14: 810-814.

[85] Tabakoglu H O, M Gulsoy (2010) In vivo comparison of near infrared lasers for skinwelding. Lasers Med Sci. 25(3): 411-421. 


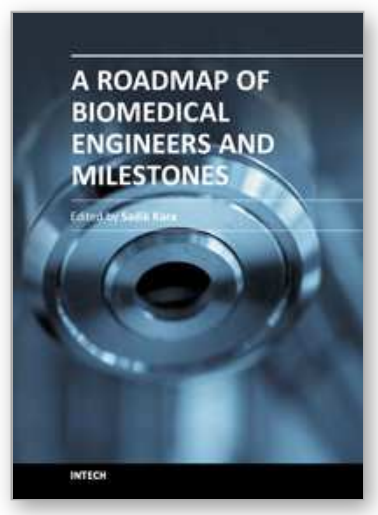

\author{
A Roadmap of Biomedical Engineers and Milestones \\ Edited by Prof. Sadik Kara
}

ISBN 978-953-51-0609-8

Hard cover, 230 pages

Publisher InTech

Published online 05, June, 2012

Published in print edition June, 2012

This book is devoted to different sides of Biomedical Engineering and its applications in science and Industry. The covered topics include the Patient safety in medical technology management, Biomedical Optics and Lasers, Biomaterials, Rehabilitat, Ion Technologies, Therapeutic Lasers \& Skin Welding Applications, Biomedical Instrument Aopplication and Biosensor and their principles.

\title{
How to reference
}

In order to correctly reference this scholarly work, feel free to copy and paste the following:

Haşim Özgür Tabakoğlu and Ayşen Gürkan Özer (2012). Therapeutic Lasers and Skin Welding Applications, A Roadmap of Biomedical Engineers and Milestones, Prof. Sadik Kara (Ed.), ISBN: 978-953-51-0609-8, InTech, Available from: http://www.intechopen.com/books/a-roadmap-of-biomedical-engineers-andmilestones/therapeutic-lasers-skin-welding-applications

\section{INTECH}

open science | open minds

\author{
InTech Europe \\ University Campus STeP Ri \\ Slavka Krautzeka 83/A \\ 51000 Rijeka, Croatia \\ Phone: +385 (51) 770447 \\ Fax: +385 (51) 686166 \\ www.intechopen.com
}

\author{
InTech China \\ Unit 405, Office Block, Hotel Equatorial Shanghai \\ No.65, Yan An Road (West), Shanghai, 200040, China \\ 中国上海市延安西路65号上海国际贵都大饭店办公楼405单元 \\ Phone: +86-21-62489820 \\ Fax: +86-21-62489821
}


(C) 2012 The Author(s). Licensee IntechOpen. This is an open access article distributed under the terms of the Creative Commons Attribution 3.0 License, which permits unrestricted use, distribution, and reproduction in any medium, provided the original work is properly cited. 